\title{
DOMNIEMANIE NIEZGODNOŚCI RABATU LOJALNOŚCIOWEGO Z PRAWEM KONKURENCJI UNII EUROPEJSKIEJ - ROZWAŻANIA NA TLE WYROKU W SPRAWIE INTEL
}

\section{WPROWADZENIE}

Coraz częstsze stosowanie domniemań $\mathrm{w}$ postępowaniach $\mathrm{z}$ zakresu prawa konkurencji Unii Europejskiej przyczyniło się w ostatnich latach do przesunięcia w znacznej mierze ciężaru dowodu z organu ochrony konkurencji na przedsiębiorstwo. Stosowanie domniemań w prawie konkurencji jest szczególnie złożone w przypadku spraw dotyczących nadużywania pozycji dominującej zakazanego na podstawie art. 102 Traktatu o funkcjonowaniu Unii Europejskiej ${ }^{1}$. Celem niniejszego artykułu jest wykazanie trudności zwiąanych z obaleniem przez dominujace przedsiębiorstwo domniemania naruszenia reguł konkurencji. $\mathrm{W}$ tym zakresie przeanalizowany zostanie wyrok Trybunału Sprawiedliwości (TS) w sprawie Intel ${ }^{2}$. W artykule zostaną także zaproponowane możliwości wzruszenia domniemania naruszenia reguł konkurencji przez dominujące przedsiębiorstwo. W artykule posłużono się metodą dogmatycznoprawna, w ramach której przeanalizowano poglądy prezentowane w literaturze przedmiotu, zarówno polskiej, jak i zagranicznej. Dzięki metodzie dogmatycznoprawnej analizie poddano również orzecznictwo Trybunału Sprawiedliwości Unii Europejskiej (TSUE).

Zasady dotyczące ciężaru dowodu obowiąującego w sprawach praktyk ograniczających konkurencję zostały uregulowane w rozporządzeniu 1/2003․ W świetle art. 2 tego rozporządzenia:

\footnotetext{
* Marzena Fähnrich, Uniwersytet Szczeciński, marzena.fahnrich@usz.edu.pl, https://orcid.org/0000-0002-5048-9866.

${ }^{1}$ Dz. Urz. UE C 202, 7 czerwca 2016 r. (dalej jako: TFUE).

${ }^{2}$ Wyrok TS z 6 września 2017 r. w sprawie C-413/14 P Intel v Komisja, ECLI:EU:C:2017:632.

${ }^{3}$ Rozporządzenie Rady (WE) nr 1/2003 z 16 grudnia 2002 r. w sprawie wprowadzenia w życie reguł konkurencji ustanowionych w art. 81 i 82 Traktatu Dz. Urz. UE L 1, 4 stycznia 2003 r. ze zm.
} 
W każdym krajowym lub wspólnotowym postępowaniu w sprawie stosowania art. 81 i 82 Traktatu ciężar udowodnienia naruszenia art. 81 ust. 1 lub art. 82 Traktatu spoczywa na stronie lub organie zarzucającym naruszenie. Przedsiębiorstwo lub związek przedsiębiorstw ubiegający się o wyłączenie na mocy art. 81 ust. 3 Traktatu ma obowiązek udowodnienia, że przesłanki określone w tym przepisie są spełnione.

Powyższy przepis oznacza, że wykazanie naruszenia zakazów określonych w art. 101 lub 102 TFUE spoczywa na Komisji Europejskiej (dalej: Komisja). Gdy Komisja w zadowalający sposób udowodni naruszenie prawa konkurencji, przedsiębiorstwo będące stroną postępowania może podnieść wystapienie którejś z przesłanek uzasadniających jego działanie na rynku, które spowodowałoby uniknięcie zakwalifikowania tego zachowania jako naruszenia prawa konkurencji, lub wykazać wystapienie korzyści kompensujacych wystapienie ograniczeń konkurencji. Udowodnienie spełniania przesłanek określonych $\mathrm{w}$ art. 101 ust. 3 TFUE należy do przedsiębiorstwa będącego stroną postępowania ${ }^{4}$. Mimo że art. 2 rozporządzenia 1/2003 nie odnosi się do analogicznych przesłanek wyłączających zastosowanie zakazu określonego w art. 102 TFUE, można przyjąć, że podejście w tej kwestii jest zbliżone do tego, o którym mowa w art. 101 ust. 3 TFUE. Przyczyny późnego uregulowania powyższej kwestii można upatrywać w tym, że prawo UE jest owocem zintegrowania wielu różnych systemów prawa i przez to wyłonienie ogólnych zasad jest trudnym zadaniem $^{5}$. W związku z powyższym doniosła rola w kształtowaniu zasad przypada Trybunałowi Sprawiedliwości. Podstawowe zasady dotyczące ciężaru dowodu określone zostały w jego orzecznictwie. W wyroku w sprawie Baustahlgewebe ${ }^{6}$, w którym TS stwierdził, że zawsze wtedy, gdy zachodzi niejasność co do wystapienia naruszenia reguł konkurencji, do Komisji należy wykazanie powyższego naruszenia. Zadaniem Komisji jest również zgromadzenie materiału dowodowego, który pozwala potwierdzić wystapienie okoliczności stanowiących naruszenie reguł konkurencji. Zawarcie w rozporzadzeniu 1/2003 konkretnego przepisu dotyczącego rozłożenia ciężaru dowodu podyktowane było właśnie potrzebą zapewnienia odpowiedniego poszanowania praw podstawowych przedsiębiorstwa na etapie przeprowadzenia postępowania wyjaśniającego przez Komisję albo krajowy organ ochrony konkurencji ${ }^{7}$.

Zastosowanie domniemania odciąża organ ochrony konkurencji we wstępnej fazie postępowania, sprawia ono bowiem, że nie jest konieczne przedstawienie materiału dowodowego w celu stwierdzenia naruszenia reguł konkurencji. Oznacza to jednocześnie, że ciężar dowodu spoczywajacy na przedsiębiorstwie, któremu przypisuje się naruszenie reguł konkurencji, będzie bardziej dotkliwy, gdyż będzie ono zmuszone do przedstawienia dowodów pozwalajacych na obalenie owego domniemania. W tym miejscu należy podkreślić, że w każdym

${ }^{4}$ Kalintiri (2015): 232-256.

${ }^{5}$ Castillo de la Torre (2009): 507.

${ }^{6}$ Wyrok ETS z 17 grudnia 1998 r. w sprawie C-185/95 P Baustahlgewebe v Komisja, ECLI:EU:C:1998:608: pkt 58.

${ }^{7} \mathrm{~W}$ tym kontekście motyw 5 preambuły do rozporządzenia 1/2003 expressis verbis odnosi się do potrzeby regulowania kwestii dotyczących ciężaru dowodu w celu ułatwienia korzystania z prawa do obrony przez przedsiębiorstwo. 
systemie prawa opartym na zasadzie praworządności domniemanie musi być wzruszalne. Stosowanie domniemań w sposób, który nie gwarantuje przestrzegania praw proceduralnych przedsiębiorstwa, może z kolei skutkować naruszeniem zasady domniemania niewinności i prawa do obrony przedsiębiorstwa $^{8}$. Warte podkreślenia jest to, że zastosowanie domniemania w postępowaniu przed organem ochrony konkurencji powinno być zawsze uzasadnione jasnymi przesłankami. W literaturze podjęto próbę określenia tego, co może stanowić racjonalne uzasadnienie zastosowania domniemania9 ${ }^{9}$.

\section{CIĘŻAR I STANDARD DOWODU W POSTĘPOWANIU ANTYMONOPOLOWYM}

Uregulowanie dotyczące ciężaru dowodu z pozoru zawarte w art. 2 rozporządzenia 1/2003 może wydawać się proste, jednakże głębsza analiza rozłożenia ciężaru dowodu w postępowaniach z zakresu prawa konkurencji wskazuje na znacznie większą złożoność powyższej kwestii, aniżeli sugerowałaby to sama lektura tego przepisu. Można założyć istnienie specyficznego, integralnego powiązania pomiędzy ciężarem a standardem (stopniem) dowodowym. Spowodowane jest to tym, że rozłożenie ciężaru dowodu (tj. na kim powinien spoczywać) wiąże się z tym, w jaki sposób obowiązek dowodowy zostanie wypełniony (tj. w jaki sposób podmiot, na którym ciąży taki obowiązek, może go spełnić) ${ }^{10}$.

Przesunięcie ciężaru dowodu w wykazaniu danej okoliczności w dużej mierze zależy od standardu dowodowego koniecznego do wykazania danego naruszenia prawa konkurencji. W sprawie T-Mobile rzecznik generalny Kokott w swojej opinii odniosła się do relacji pomiędzy pojęciem standardu dowodu a ciężaru dowodu w następujący sposób:

\footnotetext{
Standard dowodu określa wymogi, które muszą być spełnione, aby przyjać dany stan faktyczny za udowodniony. Należy go więc odróżnić od ciężaru dowodu. Ciężar dowodu determinuje, po pierwsze, to, która ze stron powinna przedstawić stan faktyczny, oraz jeżeli to konieczne, również dowody na jego istnienie (tzw. ciężar dowodowy). Po drugie, rozmieszczenie powyższego ciężaru określa, która ze stron ponosi ryzyko związane z tym, że dany stan faktyczny lub zarzuty nie zostaną udowodnione (tzw. ciężar materialny) ${ }^{11}$.
}

W praktyce powyższe oznacza, że Komisja musi przestrzegać pewnego standardu dowodu, aby móc udowodnić naruszenie prawa konkurencji i w konsekwencji nałożyć na przedsiębiorstwo sankcję. W przypadku gdy dowody wykorzystane przez Komisję są w zgodzie z powyższym standardem, to na przedsiębiorstwie ciąży obowiązek odparcia zarzutów Komisji poprzez

\footnotetext{
8 Da Cruz Vilaça (2018): 173-188.

9 Bailey (2010): 23; Ritter (2018): 16.

10 Fernández (2019): 1.

11 Opinia Rzecznika Generalnego Kokott w sprawie C-8/08T Mobile Netherlands BV and Others, ECLI:EU:C:2009: 110.
} 
przedstawienie dowodu przeciwnego. Innymi słowy, obowiązek przedstawienia dowodu zostaje przesunięty, a przedsiębiorstwo musi odeprzeć zarzuty Komisji poprzez przedstawienie własnych argumentów i własnego materiału dowodowego ${ }^{12}$.

W literaturze wskazuje się, że w rzeczywistości występują dwa aspekty pojęcia ciężaru dowodu. Po pierwsze, można mówić o tzw. ciężarze perswazji (ang. burden of persuasion), po drugie, o tzw. ciężarze dowodowym (ang. evidential burden $)^{13}$. Bez względu na to, że powyższe rozróżnienie nie istnieje pod względem prawnym, to ma ono doniosłe znaczenie w praktyce. Ciężar perswazji spoczywający na Komisji oznacza, że ma ona zebrać „konkretne i spójne dowody pozwalające na stanowcze przekonanie, że naruszenie reguł konkurencji miało miejsce" ${ }^{14}$. Powyższy standard „stanowczego przekonania” stosowany przez TSUE jest bardziej restrykcyjny niż standard prawdopodobieństwa, choć mniej surowy niż na przykład standard „przekonania poza wszelką wątpliwością" stosowany w postępowaniu karnym w większości krajowych porządków prawnych common law.

\section{DOMNIEMANIE}

Domniemanie można zdefiniować jako wykorzystanie danego, sprawdzonego faktu lub kilku faktów w celu stwierdzenia innego. Domniemanie w powyższym ujęciu nazywane jest „domniemaniem faktycznym” lub „domniemaniem dowodowym" i charakteryzuje się tym, że jest wzruszalne ${ }^{15}$. Według Komisji domniemanie jest „mechanizmem prawnym, za pomocą którego niepewny fakt jest wywnioskowany z faktu pewnego. Taki mechanizm znajduje zastosowanie wówczas, gdy dany niepewny fakt, który ze względu na swój charakter jest trudny do stwierdzenia, może być ustalony dzięki wystapieniu innego faktu, którego stwierdzenie jest łatwiejsze" ${ }^{16}$. W prawie konkurencji UE klasycznym przykładem domniemania faktycznego jest domniemanie odpowiedzialności spółki dominującej: „wystarczające jest, aby Komisja wykazała, że spółka zależna jest całkowicie własnością spółki dominującej, aby wyjść z założenia, że spółka dominująca wywiera decydujacy wpływ na politykę handlową spółki zależnej”"

${ }^{12}$ Opinia Rzecznika Generalnego Kokott w sprawie C-105/04 FEG v Komisja, ECLI:EU: C:2005:751: pkt 73.

${ }^{13}$ Fernández (2019): 2.

${ }^{14}$ Wyrok Sądu Pierwszej Instancji z 6 lipca 2000 r. w sprawie T-62/98 Volkswagen AG v Komisja, ECLI:EU:T:2000:180: pkt 43.

${ }_{15}$ Ritter (2018): 2. Zob. wyrok ETS z 7 stycznia 2004 r. w sprawie C-204/00 P Aalborg Portland $v$ Komisja, ECLI:EU:C:2004:6: pkt 79.

${ }_{16}$ Opinia Rzecznika Generalnego Bot w sprawie C-605/13 P Anbouba v Rada Unii Europejskiej, ECLI:EU:C:2015:2: pkt 50.

${ }^{17}$ Wyrok TS z 10 września 2009 r. w sprawie C-97/08 P Akzo Nobel v Komisja, ECLI:EU: C:2009:536: pkt 61. 
Korzystanie z domniemań może ułatwić Komisji oraz krajowym organom ochrony konkurencji wykazanie stosowania przez przedsiębiorstwa praktyk ograniczających konkurencję. Domniemanie jawi się zatem jako przydatny instrument, którego zastosowanie jest jednak zadaniem dość nieoczywistym. Zadanie to powinno być wykonywane zawsze z odpowiednią dbałościa i z poszanowaniem prawa do obrony przedsiębiorstwa, które powinno mieć możliwość wzruszenia domniemania ${ }^{18}$.

Domniemanie może mieć kilka źródeł (normy prawne, wytyczne, orzecznictwo). Może ono także przybierać różne formy (proceduralne, faktyczne lub prawne). Ponadto domniemanie może być wzruszalne i niewzruszalne. Domniemanie pozwala na uniknięcie szczegółowej analizy ekonomicznej w określonych przypadkach - prowadzi do ograniczenia kosztów stosowania prawa konkurencji i minimalizuje ryzyko wystapienia błędów ${ }^{19}$. W każdym systemie prawa, w którym organy administracji i sądy posiadają ograniczone zasoby, zastosowanie domniemania może pomóc nie tylko w uporządkowaniu postępowania na etapie dowodowym, lecz także umożliwia przyspieszenie postępowania i sprawia, że złożone kwestie stają się łatwiejsze w zarządzaniu ${ }^{20}$.

Zastosowanie domniemań w prawie konkurencji UE jest dość powszechne. Można przywołać wiele przykładów takich zastosowań. Jednym z nich, jest domniemanie zawarcia antykonkurencyjnego porozumienia z tytułu samego uczestniczenia w spotkaniach, na których uzgadniano jego warunki ${ }^{21}$.

Wyrok TS w sprawie Cartes Bancaires zdyscyplinował w pewien sposób rozszerzającą się tendencję stosowania domniemań w zakresie art. 101 TFUE. Trybunał Sprawiedliwości przypomniał w powyższym wyroku, że:

[...] błędnie z punktu widzenia tego orzecznictwa Sąd uznał w pkt 124 zaskarżonego wyroku, a następnie - w jego pkt 146, że pojęcia „ograniczenia konkurencji ze względu na cel” nie można interpretować „zawężająco”. Pojęcia „ograniczenia konkurencji ze względu na cel” nie można bowiem zastosować do niektórych rodzajów współpracy między przedsiębiorstwami, które sa szkodliwe dla konkurencji w stopniu wystarczającym do tego, aby nie było konieczności badania ich skutków, nie zwalniając jednocześnie Komisji z obowiązku dowiedzenia konkretnych skutków, jakie pociagają za sobą na rynku te porozumienia, w odniesieniu do których nie wykazano, iż ze względu na swój charakter są one szkodliwe dla prawidłowego funkcjonowania normalnej gry rynkowej. Bez znaczenia jest w tym względzie okoliczność, że rodzaje porozumień wskazanych w art. 81 ust. $1 \mathrm{WE}$ nie stanowią wyczerpującego wykazu zakazanych zmów ${ }^{22}$.

${ }^{18}$ Da Cruz Vilaça (2018): 175.

${ }^{19}$ OECD, Executive Summary of the Roundtable on Safe Harbours and Legal Presumptions in Competition Law, Annex to the Summary Record of the 128th Meeting of the Competition Committee held on 5-6 December 2017: 2.

${ }^{20}$ OECD, Roundtable on Safe Harbours and Legal Presumptions in Competition Law - Note by the European Union, 5 December 2017: 2.

${ }_{21}$ Opinia Rzecznika Generalnego Kokott w sprawie T-Mobile.

${ }^{22}$ Wyrok TS z 11 września 2014 r. w sprawie C-67/13 P Groupement des Cartes Bancaires (CB) v Komisja, ECLI:EU:C:2014:2204: pkt 58. 


\section{RABATY LOJALNOŚCIOWE (,ZA WYŁĄCZNOŚĆ”)}

Punktem wyjścia dyskusji dotyczącej domniemań w obszarze rabatów lojalnościowych w kontekście art. 102 TFUE jest wyrok Europejskiego Trybunału Sprawiedliwości (ETS) w sprawie Hoffman-La Roche ${ }^{23}$. W sprawie tej ETS ustanowił domniemanie, w świetle którego przedsiębiorstwo posiadające pozycję dominująca, wiążące swoich klientów postanowieniami o charakterze wyłączności na dostawy (nawet na prośbę samego klienta), nadużywa pozycji dominującej w rozumieniu obecnego art. 102 TFUE. Nadużycie pozycji dominującej, według ETS, zachodzi bez względu na to, czy obowiązek „lojalności”, „wyłączności” jest uzgodniony jednocześnie z innymi obowiązkami czy też w zamian za przyznanie rabatów ${ }^{24}$.

Ponadto ETS stwierdził w wyroku w sprawie Hoffman-La Roche, że podobne domniemanie ma zastosowanie do dominującego przedsiębiorstwa, które posługuje się systemem rabatów lojalnościowych w przypadku, gdy przedsiębiorstwo jest jedynym dostawca danego klienta ${ }^{25}$. Powyższe stanowisko ETS uzasadnił w ten sposób, że posługiwanie się rabatami lojalnościowymi nie jest oparte na transakcji handlowej, która mogłaby je usprawiedliwiać, a raczej polega na pozbawieniu nabywcy bądź ograniczeniu mu możliwych źródeł zaopatrzenia i tym samym skutkuje uniemożliwieniem innym przedsiębiorstwom dostępu do rynku²6.

W odnośnym wyroku ETS wyraźnie rozróżnił rabaty lojalnościowe i ilościowe. Rabaty lojalnościowe w odróżnieniu od rabatów ilościowych, które dotyczą ilości zakupionych towarów od danego przedsiębiorcy, są skonstruowane w taki sposób, aby zapewnić korzyści finansowe klientom w zamian za uniknięcie zaopatrywania się przez nich u konkurentów przedsiębiorstwa ${ }^{27}$. Domniemywa się zatem, że rabaty ilościowe są zgodne z zasadami konkurencji, natomiast rabaty lojalnościowe nie.

Podnosi się, że w sprawie Hoffman-La Roche ETS zignorował fakt, że rabaty lojalnościowe moga spełniać kryteria wyłaczenia spod zakazu praktyk ograniczających konkurencję określonych w art. 101 ust. 3 TFUE. Powyższej kwestii przyjrzano się dopiero w sprawie Inte ${ }^{28}$.

\section{SPRAWA INTEL}

Niedługo po ogłoszeniu wytycznych w sprawie priorytetów, którymi Komisja ma się kierować przy stosowaniu art. $82^{29}$ Traktatu WE ${ }^{30}$, unijny organ

${ }^{23}$ Wyrok ETS z 13 lutego 1979 r. w sprawie 85/76 Hoffman-La Roche \& Co AG v Komisja, ECLI:EU:C:1979: 36.

${ }^{24}$ Wyrok ETS w sprawie Hoffman-La Roche: pkt 89.

${ }^{25}$ Ibid.

${ }^{26}$ Ibid.: pkt 90.

${ }^{27}$ Ibid.

${ }^{28}$ Fernández (2019): 4.

${ }^{29}$ Art. 82 Traktatu WE został zastapiony przez art. 102 TFUE po wejściu w życie Traktatu z Lizbony, czyli po 1 grudnia $2009 \mathrm{r}$.

${ }^{30}$ Komunikat Komisji - wytyczne w sprawie priorytetów, którymi Komisja będzie się kierować przy stosowaniu art. 82 Traktatu WE w odniesieniu do szkodliwych działań o charakterze 
ochrony konkurencji wydał decyzję w znanej sprawie Intel ${ }^{31}$. Decyzją z 13 maja 2009 r. Komisja nałożyła na spółkę Intel wysoką karę pieniężna, stwierdzając nadużycie przez amerykańskie przedsiębiorstwo pozycji dominującej na rynku, na którym posiadało 70 procent udziału. Według Komisji nadużycie pozycji dominującej miało nastapić między innymi przez przyznawanie przez Intel swoim klientom rabatów lojalnościowych z tytułu zaopatrywania się przez nich wyłącznie lub $\mathrm{w}$ istotnym zakresie $\mathrm{w}$ procesory wyprodukowane przez Intel. Taka praktyka według Komisji doprowadzić miała do eliminacji z rynku głównego konkurenta przedsiębiorstwa Intel - spółki AMD, przez uniemożliwienie jej dostępu do głównych kanałów dystrybucji.

Decyzja Komisji została zaskarżona do Sądu, który zgodnie z wyrokiem w sprawie Hoffman-La Roche podtrzymał zaskarżoną przez Intel decyzję Komisji. Sąd odrzucił tym samym argumenty przedsiębiorstwa dotyczące tego, że przeprowadzona analiza sytuacji na rynku w okresie rzekomego naruszenia była nieprawidłowa i przez to stosowane przez Intel rabaty nie miały antykonkurencyjnego charakteru ${ }^{32}$. Sąd wskazał ponadto, że stosując ustanowione w wyroku w sprawie Hoffman-La Roche domniemanie niezgodności z prawem konkurencji rabatów lojalnościowych stosowanych przez dominujące przedsiębiorstwo, należy uznać, że przedsiębiorstwo Intel dopuściło się naruszenia reguł konkurencji. Według Sądu jest tak, ponieważ rabaty za wyłączność nie stanowią praktyki cenowej, a raczej sa rodzajem uzgodnienia w zakresie zaopatrzenia o charakterze wyłącznym lub quasi-wyłącznym ${ }^{33}$. Sąd w związku z tym nie uwzględnił argumentu przedsiębiorstwa Intel dotyczacego zastosowania testu AEC (ang. as-efficient competitor test) czy testu równie skutecznego konkurenta (zgodnie z wytycznymi Komisji), wskazując, że wyniki testu nie były w stanie zmienić i tak abuzywnej natury rabatów za wyłączność stosowanych przez Intel ${ }^{34}$.

Wyrok Sądu w sprawie Intel wywołał ożywioną dyskusję wśród przedstawicieli doktryny. Wyrok ten okazał się rozczarowujący szczególnie dla tych, którzy liczyli na przyjęcie przez Sąd tzw. podejścia opartego na efektach (ang. effects-based approach), w tym testu AEC (równie efektywnego konkurenta) jako nowego, standardowego instrumentu oceny rabatów warunkowych w świetle art. 102 TFUE $^{35}$. Inni komentatorzy z kolei bronili stanowiska Sądu w kwestii użyteczności testu AEC. W tym zakresie podniesiono, że test ten oparty jest na założeniu, że czynnikiem decydujacym dla klienta jest cena, przy pominięciu wpływu takich elementów, jak jakość czy różno-

praktyki wyłączającej, podejmowanych przez przedsiębiorstwa dominujace, Dz. Urz. UE C 45, 24 lutego 2009 r.: $7-20$.

${ }^{31}$ Decyzja Komisji z 22 września 2009 r. w sprawie COMP/C-3/37.990 Intel, Dz. Urz. C 227: $13-17$.

${ }^{32}$ Wyrok Sądu z 12 czerwca 2014 r. w sprawie T-286/09 Intel v Komisja, ECLI:EU:T:2014:547: pkt 99.

${ }^{33}$ Ibid.; Kadar (2019): 4.

${ }^{34}$ Test równie skutecznego konkurenta jest metodą ekonomiczna, która pozwala na obliczenie tego, czy możliwe jest, aby hipotetyczny równie skuteczny konkurent mógł zastosować rabaty odpowiadające tym, które stosuje przedsiębiorstwo dominujące. Zob. Kadar (2019): 4.

${ }^{35}$ Bułakowski (2017): 42; Nihoul (2014): 530. 
rodność produktów ${ }^{36}$. Wobec tego przy ocenie rabatów warunkowych nie jest właściwe uwzględnianie jedynie sytuacji równie skutecznych konkurentów. Jest tak dlatego, że mniej skuteczne przedsiębiorstwo również może wywierać presję konkurencyjną na przedsiębiorstwo dominujące z korzyścią dla konsumentów ${ }^{37}$.

Po wyroku Sądu w sprawie Intel, 20 października 2016 r., rzecznik generalny Wahl wydał opinię rekomendującą TS uchylenie go. Według rzecznika generalnego Sąd dokonał błędnego rozróżnienia pomiędzy rabatami za wyłaczność i innymi rabatami warunkowymi. Jak bowiem stwierdził, właściwe rozróżnienie powinno nastapić pomiędzy rabatami ilościowymi (objętymi domniemaniem zgodności z prawem konkurencji) oraz tymi rabatami, które wymagają oceny wszystkich okoliczności sprawy ${ }^{38}$. Co więcej, według krytyków wyroku Sądu w sprawie Intel objęcie rabatów „za wyłączność” zakazem o charakterze per se lub quasi-per se wynika z błędnego pojmowania tego rodzaju praktyki jako stosowanej zawsze w celach wykluczających i wiążącej się przez to z wywołaniem antykonkurencyjnych skutków. W rzeczywistości rabaty „za wyłączność" mogą być stosowane również w innych celach, w tym o charakterze prokonkurencyjnym, co oznacza, że przesądzanie o ich szkodliwości jest na wyrost ${ }^{39}$.

Trybunał Sprawiedliwości 6 września 2017 r. w sprawie Intel TS uchylił wyrok wydany przez Sąd i przypomniał, że art. 102 TFUE nie ma na celu uniemożliwienia przedsiębiorstwu zdobycia, dzięki jego własnym świadczeniom, dominującej pozycji na rynku. Jak wskazał TS, przepis ten nie zmierza również do zapewnienia, aby konkurenci mniej skuteczni niż przedsiębiorstwo zajmujące pozycję dominująca pozostali na rynku ${ }^{40}$. Nie każdy skutek w postaci wykluczenia musi koniecznie prowadzić do naruszenia konkurencji. Z definicji konkurencja oparta na jakości może doprowadzić do zniknięcia z rynku lub do odsunięcia na dalszy plan konkurentów mniej skutecznych, a zatem mniej interesujących dla konsumentów, w szczególności pod względem cen, możliwości wyboru, jakości i innowacyjności ${ }^{41}$.

Artykuł 102 TFUE zakazuje przedsiębiorstwu zajmujacemu pozycję dominująca stosowania praktyk powodujących wykluczenie równie skutecznych konkurentów oraz praktyk wzmacniających jego pozycję za pomocą środków innych niż konkurencja oparta na jakości. Oznacza to, jak podał TS, że z tej perspektywy nie każda konkurencja cenowa może być uznana za zgodną z prawem $^{42}$. W tym kontekście TS przypomniał, że w przypadku przedsiębiorstwa zajmującego dominującą pozycję na rynku fakt związania nabywców - nawet

36 Wils (2014): 28.

37 Wils (2014): 29.

${ }^{38}$ Opinia Rzecznika Generalnego Wahl w sprawie C-413/14 P Intel v Komisja, ECLI:EU: C:2016:788: pkt 66 .

39 Ibáñez Colomo (2014): 4.

40 Wyrok TS w sprawie Intel: pkt 133.

41 Ibid.: pkt 134. Zob. też wyrok TS z 27 marca 2012 r. w sprawie C-209/10 Post Danmark, EU:C:2012:172: pkt 22 i przytoczone tam orzecznictwo.

${ }^{42}$ Wyrok TS w sprawie Intel: pkt 136. 
na ich wniosek - obowiązkiem lub obietnica zaopatrywania się wyłącznie w tym przedsiębiorstwie celem pokrycia całości lub znacznej części ich zapotrzebowania stanowi nadużywanie dominującej pozycji w rozumieniu art. 102 TFUE. Jak dodał TS, nieistotne jest przy tym, czy to zobowiązanie zostało zaciagnięte bez dodatkowych zastrzeżeń czy też w zamian za przyznanie rabatu. To samo dotyczy sytuacji, w której takie przedsiębiorstwo, nie nakładając na nabywców formalnego obowiązku, stosuje, na mocy umów zawartych z tymi nabywcami, system rabatów lojalnościowych, czyli upustów przyznawanych pod warunkiem, że klient zaopatruje się w celu pokrycia całości lub istotnej części swojego zapotrzebowania wyłącznie w przedsiębiorstwie zajmujacym pozycję dominująca ${ }^{43}$.

Co istotne jednak, TS w wyroku w sprawie Intel podkreślił, że powyższe domniemanie ma charakter wzruszalny. Jak stwierdził bowiem TS, gdy dane przedsiębiorstwo w toku postępowania administracyjnego podnosi dowody na poparcie tego, że jego zachowanie nie miało zdolności do ograniczenia konkurencji, w szczególności wywołania skutków zarzucanego wykluczenia, Komisja jest zobowiązana do zbadania pozycji dominującej przedsiębiorstwa, warunków i sposobów przyznawania rabatów, a także ma obowiązek przeprowadzenia oceny strategii mającej na celu wykluczenie z rynku równie skutecznych konkurentów ${ }^{44}$. Trybunał Sprawiedliwości nie odniósł się tym samym do tego, czy rabaty lojalnościowe powinny być poddane przez Komisję testowi AEC podczas przeprowadzania przez nią swojej analizy ${ }^{45}$.

Trybunał Sprawiedliwości stwierdził, że analiza Sądu dokonana w sprawie Intel powinna była obejmować argumenty przedsiębiorstwa w przedmiocie testu AEC przeprowadzonego przez Komisję. Przedsiębiorstwo Intel podniosło bowiem, że zastosowanie przez Komisję testu AEC wpłynęło na jej ocenę tego, czy rabaty lojalnościowe w sprawie mogły ograniczać konkurencję ${ }^{46}$. Ze względu na to, że analiza Sądu nie objęła poprawności zastosowania testu AEC przez Komisję, TS postanowił uchylić wyrok Sądu.

\section{WZRUSZENIE DOMNIEMANIA NIEZGODNOŚCI Z PRAWEM KONKURENCJI RABATÓW LOJALNOŚCIOWYCH}

Wskazuje się, że możliwe są trzy sposoby wzruszenia domniemania niezgodności z prawem konkurencji rabatów lojalnościowych ${ }^{47}$. Jak stwierdził TS w wyroku w sprawie Intel:

Analiza zdolności wykluczającej jest również istotna dla oceny kwestii, czy system rabatów wchodzący zasadniczo w zakres zakazu ustanowionego w art. 102 TFUE może być obiektywnie uzasadniony. Ponadto wynikające z systemu rabatów skutki wykluczenia, niekorzystne

\footnotetext{
${ }^{43}$ Ibid.: pkt 137. Zob. też zob. wyrok ETS w sprawie Hoffman-La Roche: pkt 89.

${ }_{44}$ Ibid.: pkt 138 i 139. Zob. analogicznie wyrok TS w sprawie Post Danmark: pkt 29.

45 Kadar (2019): 6.

${ }^{46}$ Wyrok TS w sprawie Intel: pkt 141-143.

47 Fernández (2019): 6.
} 
dla konkurencji, mogą zrównoważyć, czy też przeważyć korzyści pod względem efektywności, z których ma pożytek również konsument (wyrok z dnia 15 marca 2007 r., British Airways/Komisja, C-95/04 P, EU:C:2007:166, pkt 86). Takie wyważenie skutków kwestionowanej praktyki - korzystnych i niekorzystnych dla konkurencji - może być dokonane w decyzji Komisji dopiero po przeprowadzeniu związanego z analizowaną praktyką badania potencjału w zakresie wykluczenia konkurentów przynajmniej tak samo skutecznych jak przedsiębiorstwo zajmujące pozycję dominującą ${ }^{48}$.

Pierwszy sposób wzruszenia domniemania, o którym mowa powyżej, polega na tzw. obiektywnym uzasadnieniu zastosowania rabatu lojalnościowego. Obecnie nie ma jednoznacznej definicji tego pojęcia. Zastosowanie obrony polegającej na obiektywnym uzasadnieniu wymaga indywidualnego podejścia do każdej sprawy i jest uwzględniane przez sądy tylko w wyjątkowych okolicznościach ${ }^{49}$. Do pojęcia obiektywnego uzasadnienia odniósł się TS w wyroku w sprawie United Brands. Jak stwierdził TS:

pomimo tego, że prawdą jest, tak jak wskazują skarżący, że fakt posiadania przez przedsiębiorstwo pozycji dominującej nie może pozbawiać go prawa do ochrony własnych interesów handlowych i że w związku z tym przedsiębiorstwo to może podejmować racjonalne kroki, które uważa za stosowne w celu ochrony tych interesów, to jednakże takie zachowanie jest niedozwolone, jeżeli jego faktycznym celem jest wzmocnienie pozycji dominującej i nadużycie jej jo

Drugi sposób wzruszenia domniemania niezgodności z prawem konkurencji rabatów lojalnościowych odnosi się do argumentu wzrostu efektywności (ang. efficiency defence). Jak stwierdził TS w sprawie Intel:

[...] Ponadto wynikające z systemu rabatów skutki wykluczenia, niekorzystne dla konkurencji, mogą zrównoważyć, czy też przeważyć korzyści pod względem efektywności, z których ma pożytek również konsument $[\ldots]^{51}$.

Niestety do dziś nie istnieje ani jeden przykład skutecznego powołania się przez przedsiębiorstwo na powyższy argument na podstawie art. 101 ust. 3 TFUE, jeżeli Komisja wykaże, że dana praktyka stanowi ograniczenie konkurencji ze względu na cel. Co więcej, przepisy TFUE nie zawierają analogicznego unormowania w przypadku art. 102 (nie ma przecież art. 102 ust. 3 TFUE). Warto podkreślić jednak, że w wytycznych Komisja zdecydowała się zastosować podejście określone w art. 101 ust. 3 TFUE dotyczące wzrostu efektywności w przypadku art. 102 TFUE $^{52}$. Wytyczne te wskazują cztery przesłanki,

${ }^{48}$ Wyrok TS w sprawie Intel: pkt 140.

${ }^{49}$ Communication from the Commission - Guidance on the Commission's enforcement priorities in applying Article 82 of the EC Treaty to abusive exclusionary conduct by dominant undertakings (Guidance Paper) (2009) Dz. Urz. UE C45/7: pkt 28-31.

${ }^{50}$ Wyrok TS w sprawie 27/76 United Brands v Komisja, ECLI:EU:C:1978:22: pkt 189. Zob. też sprawy C-457/10P Astra Zeneca v Komisja, ECLI:EU:C:2012:770: pkt 129; T-30/89 Hilti $v$ Komisja, ECLI:EU:T:1991:70: pkt 118.

${ }^{51}$ Wyrok TS w sprawie Intel: pkt 140.

${ }^{52}$ Communication from the Commission-Guidance on the Commission's enforcement priorities in applying Article 82 of the EC Treaty to abusive exclusionary conduct by dominant undertakings (Guidance Paper), 
które powinny być spełnione w celu powołania się przez przedsiębiorstwo, któremu zarzuca się naruszenie reguł konkurencji, na argument wzrostu efektywności. Przesłanki te odzwierciedlają te, o których mowa w art. 101 ust. 3 TFUE. Niniejsze podejście zostało potwierdzone przez TS w wyroku w sprawie Post Danmark, w którym stwierdził, że:

[...] do przedsiębiorstwa zajmujacego pozycję dominującą należy wykazanie, że wzrost efektywności mogący wynikać z danego działania neutralizuje wszelkie przypuszczalne szkodliwe skutki dla konkurencji i interesów konsumentów na rynkach, na które działanie ma wpływ, że wzrost efektywności był lub mógł być osiagnięty dzięki temu zachowaniu, że owo zachowanie jest niezbędne dla osiagnięcia tych korzyści w postaci wzrostu efektywności i że nie wyklucza ono skutecznej konkurencji poprzez wyeliminowanie wszystkich lub większości źródeł rzeczywistej lub potencjalnej konkurencji53.

W rzeczywistości jednak zastosowanie do art. 102 TFUE czterech przesłanek określonych w art. 101 ust. 3 TFUE jest problematyczne do tego stopnia, że wzruszenie domniemania nadużywania pozycji dominujacej $\mathrm{w}$ tym przypadku jest skuteczne raczej w teorii niż w praktyce. Pierwszym z nich jest, że Komisja (oraz inne organy ochrony konkurencji) stosują bardzo wysoki standard weryfikacji wzrostu efektywności, kierując się bardzo trudnym do spełnienia kryterium niezbędności. Komisja ocenia efektywność praktyki stosowanej przez dominujace przedsiębiorstwo właśnie przez pryzmat posiadanej przez nie pozycji na rynku. Wskazuje się, że takie podejście nie jest zgodne z zasadami ekonomii ${ }^{54}$.

Trzeci sposób wzruszenia domniemania niezgodności z prawem konkurencji rabatów „za wyłączność” sprowadza się do udowodnienia, że zachowanie przedsiębiorstwa nie ma skutku wykluczającego. Według TS w sprawie Intel:

Takie wyważenie skutków kwestionowanej praktyki - korzystnych i niekorzystnych dla konkurencji - może być dokonane w decyzji Komisji dopiero po przeprowadzeniu związanego $\mathrm{z}$ analizowaną praktyką badania potencjału w zakresie wykluczenia konkurentów przynajmniej tak samo skutecznych jak przedsiębiorstwo zajmujące pozycję dominująca ${ }^{55}$.

Wskazuje się, że powyższy sposób wzruszenia domniemania ma charakter pośredni pomiędzy obiektywnym uzasadnieniem a argumentem wzrostu efektywności. Nawet jeżeli nie istnieje obiektywne uzasadnienie zastosowanej praktyki, jeżeli przedsiębiorstwo jest w stanie wykazać, że jego zachowanie nie miało skutku wykluczającego konkurentów (tak skutecznych jak dominujace przedsiębiorstwo), zachowanie przedsiębiorstwa może być usprawiedliwione bez potrzeby wykazania wzrostu efektywności. W świetle wyroku w sprawie Intel powyższa obrona powinna była być podniesiona na etapie postępowania przed Komisja. Jeżeli Komisja odrzuci obronę przedsiębiorstwa (wykazując, że strategia przedsiębiorstwa miała na celu wykluczenie równie skutecznych

${ }^{53}$ Wyrok TS w sprawie Post Danmark: pkt 42.

${ }^{54}$ Fernández (2019): 7; zob. tė̇ Symposium: Efficiency Claims: What's New? (2016)2(1) Competition Law \& Policy Debate: 30-75.

55 Wyrok TS w sprawie Intel: pkt 140. 
konkurentów) zadaniem Sądu jest sprawdzenie, czy analiza Komisji odrzucająca podniesioną obronę była zgodna z prawem. Obrona dotycząca wzrostu skuteczności może mieć znaczenie dopiero wtedy, gdy Sąd uzna, że analiza dokonana przez Komisję była prawidłowa.

Ciekawym pomysłem w ocenie zgodności z prawem konkurencji rabatów lojalnościowych jest podejście oparte na kwalifikowanej regule rozsądku. Podejście to zakłada trzy etapy działania. Pierwszym etap polega na ocenie tego, czy rabat wywołuje lub prawdopodobnie może wywoływać wyłaczenie segmentu rynku z konkurencji, a zatem ocenę tego, czy klienci w danej sytuacji nie są w stanie zwrócić się do konkurentów przedsiębiorstwa dominującego. Następny etap dotyczy stwierdzenia, czy wyłączony udział rynku ma znaczący charakter. Jeżeli tak, w ramach trzeciego etapu konieczne jest stwierdzenie, czy istnieją pozytywne skutki udzielanych rabatów, i zbadanie, czy równoważą one negatywne efekty ich zastosowania ${ }^{56}$.

\section{PODSUMOWANIE}

Wzruszenie domniemania niezgodności z prawem konkurencji rabatów za wyłączność należy do przedsiębiorstwa, które musi wykazać, dlaczego w danym przypadku domniemanie nie ma zastosowania. Ciężar dowodu w związ$\mathrm{ku}$ z tym przesuwa się z organu ochrony konkurencji na przedsiębiorstwo, które musi przedstawić dostateczne dowody obalajace domniemanie, korzystając z wariantów obrony omówionych powyżej. Dopiero wtedy, gdy przedsiębiorstwu uda się wzruszyć domniemanie, ciężar dowodu spoczywa na organie ochrony konkurencji. Do tej pory TS nie wskazał, jaki jest standard dowodu spoczywajacy na Komisji w wykazaniu naruszenia prawa konkurencji w przypadku rabatów lojalnościowych ${ }^{57}$. Wiadomo jednak, że TS w wyroku w sprawie Intel nie podzielił opinii rzecznika generalnego Wahl, według której prawdopodobieństwo naruszenia reguł konkurencji powinno być wysokie, aby domniemanie miało zastosowanie ${ }^{58}$.

Wyrok TS w sprawie Intel jawi się jako próba zachowania pewności prawa i zapewnienia organom ochrony konkurencji pewnej elastyczności w wykorzystaniu instrumentów, za pomocą których moga wykazać potencjalne skutki stosowanych praktyk ${ }^{59}$. Wyrok ten skłania do dwóch podstawowych wniosków w odniesieniu do art. 102 TFUE. Po pierwsze, art. 102 TFUE ma zastosowanie

${ }^{56}$ Geradin (2015): 604-606.

57 Fernández (2019): 7.

58 Opinia Rzecznika Generalnego Wahl: pkt 117: „potencjał czy też prawdopodobieństwo naruszenia reguł konkurencji oznacza, że musi być poddany obowiązkowej analizie celem, której ma być określenie, czy stosowanie rabatów lojalnościowych może stanowić naruszenie reguł konkurencji, natomiast potencjał ten, czy prawdopodobieństwo musi być znacznie większe niż zwykła możliwość, że pewne zachowanie może ograniczać konkurencję".

59 Kadar (2019): 8. 
jedynie do praktyk wykluczających konkurentów, którzy są równie skuteczni jak dominujace przedsiębiorstwo. Dla konsumentów bowiem wykluczenie z rynku konkurentów, którzy są mniej atrakcyjni, jest naturalnym skutkiem rywalizacji rynkowej i nie stanowi problemu dla prawa konkurencji. Po drugie, w wyroku w sprawie Intel TS stwierdził, że art. 102 TFUE ma zastosowanie tylko do takich praktyk, które mogą mieć antykonkurencyjny skutek. Oznacza to, że przedsiębiorstwo zawsze powinno mieć możliwość przedstawienia dowodu świadczącego o tym, że stosowana praktyka nie wywiera powyższego skutku. Dominujące przedsiębiorstwo powinno mieć możliwość wzruszenia domniemania, na którym prima facie bazuje zakaz stosowania rabatów „za wyłączność" ${ }^{\prime \prime}$. Gdy domniemanie jest niemożliwe do obalenia, nie tylko dochodzi do naruszenia zasady domniemania niewinności, ale sprawia to, że prawo konkurencji staje się trudniejsze w egzekwowaniu, gdyż może to wpłynąć na zwiększenie się liczby tzw. błędów I typu (błędnych stwierdzeń naruszenia reguł konkurencji) ${ }^{61}$.

Bailey, D. (2010). Presumptions in EU Competition Law. European Competition Law Review 31(9): 21-27.

Bułakowski, K. (2017). Rabaty stosowane przez przedsiębiorstwa dominujące w świetle orzecznictwa TSUE w latach 2011-2015. Internetowy Kwartalnik Antymonopolowy i Regulacyjny 5(6): $28-45$.

Castillo de la Torre, F. (2009). Evidence, proof and judicial review in cartel cases. World Competition 32(4): 505-578.

Da Cruz Vilaça, J.L. (2018). The intensity of judicial review in complex economic matters - recent competition law judgments of the Court of Justice of the EU. Journal of Antitrust Enforcement 6(2): 173-188.

Fernández, C. (2019). Presumptions and burden of proof in EU competition law: the Intel judgement. Journal of European Competition Law and Practice 10(7): 448-456.

Geradin, D. (2015). Loyalty rebates after Intel: time for the European Court of Justice to overrule Hoffman-La Roche. Journal of Competition Law and Economics 11(3): 579-615.

Ibáñez Colomo, P. (2014). Intel and article 102 TFEU case law: making sense of a perpetual controversy. LSE Legal Studies Working Paper No. 29: 2-14.

Ibáñez Colomo, P. (2018). The future of article 102 TFEU after Intel. Journal of European Competition Law and Practice 9(5): 293-303.

Kadar, M. (2019). Article 102 and exclusivity rebates in a post-Intel world: lessons from the Qualcomm and Google Android cases. Journal of European Competition Law and Practice 10(7): $439-447$.

Kalintiri, A. (2015). The allocation of the legal burden of proof in article 101 TFEU cases: a "clear" rule with not-so-clear Implications. Yearbook of European Law 34: 232-256.

Nihoul, P. (2014). The ruling of the General Court in Intel: towards the end of an effect-based approach in European competition law? Journal of Competition Law and Practice 5(8): 521-530.

Ritter, C. (2018). Presumptions in EU Competition Law. Journal of Antitrust Enforcement 6(2): $189-212$.

Wils, W. (2014). The judgment of the EU General Court in Intel and the so-called more economic approach to abuse of dominance. World Competition 37(4): 405-434.

60 Ibáñez Colomo (2018): 24.

${ }^{61}$ Fernández (2019): 8. 


\section{PRESUMPTION OF THE ILLEGALITY OF EXCLUSIVITY REBATES \\ IN EUROPEAN UNION COMPETITION LAW: \\ CONSIDERATIONS RELATING TO THE JUDGMENT OF THE COURT OF JUSTICE \\ IN THE INTEL CASE}

Sum mary

The increasing application of presumptions in European Union competition law proceedings in recent years has contributed to a shift of the burden of proof away from competition authorities to undertakings. The use of presumptions is particularly complex in cases concerning the abuse of a dominant position under Article 102 of the Treaty on the functioning of the European Union. This article indicates a number of problems related to challenging the presumption of the breach of competition rules by a dominant undertaking. The judgment of the Court of Justice in the Intel case provides an interesting background for the analysis in the above context. The article also seeks to offer solutions as to how a dominant undertaking can rebut the presumption of a breach of competition law.

Keywords: EU competition law; presumption; Article 102 TFEU; Intel case 